\title{
ANALISIS MANAJEMEN PEMELIHARAAN TERNAK ITIK PETELUR DI KECAMATAN KAKAS BARAT KABUPATEN MINAHASA
}

\author{
Dewi Mamarimbing, J.K.J Kalangi*, B.F.J Sondakh, J. Lainawa \\ Fakultas Peternakan Universitas Sam Ratulangi Manado, 95115
}

\begin{abstract}
ABSTRAK
Penelitian ini dilakukan di Kecamatan Kakas Barat Kabupaten Minahasa pada bulan Juli sampai dengan bulan agustus 2016. Penelitian ini bertujuan untuk mengetahui apakah peternak itik petelur telah menerapkan fungsi-fungsi manajemen (perencanaan, pengorganisasian, penerapan dan pengasawan) dalam sistem pemeliharaan itik petelur dan mendeskripsikan karateristik usaha peternak itik petelur.Dalam penelitian ini, satuan analisis (unit analisis) dalam rumahtangga peternak itik petelur dengan metode pengambilan data dilakukan melalui metode survei lapangan. Metode penentuan sampel dilakukan dalam 2 tahap dilakukan secara purposive sampling: pertama, penentuan desa sampel berdasarkan kriteria : desa yang memiliki ternak itik diatas 200 ekor.Penentuan sampel responden : memiliki ternak itik minimal 200 ekor, dan sudah berternak lebih dari 1tahun.Desa Kalawiran, Paso, Totolan, Wasian, Touliang, Panasen dan Tontimomor ditetapkan sebagai lokasi penelitian secara purposive sampling bedasarkan pertimbangan : Desa-desa tersebut memiliki populasi ternak minimal 200 ekor ternak itik petelur dan sudah lebih dari 1 tahun memelihara ternak itik petelur. Dalam penelitian ini metode pengambilan data dilakukan melalui survei lapangan. Data yang diambil meliputi data primer dan sekunder. Metode penentuan desa sampel ditentukan berdasarkan kriteria yaitu desa yang memiliki populasi itik diatas 200ekor dan purposive sampling

*Korespondensi (corresponding Author)

Email: jolanda_kalangi@yahoo.com

untuk menentukan sampel responden berdasarkan pertimbangan : memiliki populasi minimal 200 ekor ternak dan sudah lebih dari 1 tahun beternak. Metodeanalisis yang digunakan adalah analisis deskriptif untuk menguraikan secara kualitatif. Analisis kualitatif untuk mengidentifikasi dan mendeskripsikan prinsip-prinsip manajemen yang dilakukan dalam kegiatan pemeliharaan ternak itik. Hasil penelitian menunjukan karateristik responden yaitu tingkat pendidikan responden tidak tamat SD (18\%), SD(14\%), SMP (32\%), SMA (36\%), lama usaha <5tahun 2(9\%), 6-10 11(50\%), >11 tahun 9(41\%). Kepemilikan ternak 276350 ekor sebanyak 8 responden (36\%), 200-275 ekoer sebanyak 9 responden (40\%), 351-375 ekor sebanyak 1 responden $(5 \%)$. Tenaga kerja diperoleh 22 responden $(100 \%)$ menggunakan tenaga kerja dalam keluarga. Hasil analisis manajemen(perencanaan,

pengorganisasian, pelaksanaan dan pengawasan) diperoleh bahwa pemeliharaan ternak itik petelur pada umumnya peternak telah menerapkan fungsi-fungsi manajemen dalam aspek pemeliharaan ternak itik yang dilakukan secara tradisonal. Peternak yang telah menerapkan perencanaan diperoleh 22 responden $(100 \%)$, pengawasan diperoleh 22 responden $(100 \%)$, sedangkan untuk manajemen perorganisasian dan pelaksanaan didapati hanya 3 responden (14\%) yang melakukan, peternak yang tidak melakukan atau belum menerapkan sebanyak 9 responden (86\%), karena kebanyakan peternak hanya mengandalkan ingatan saja. Hal tersebut dapat menjadi suatu kelemahan dalam pengembangan
\end{abstract}


usaha peternak. Peternak dalam usaha pemeliharaan ternak itik petelur hanya menggunakan tenaga kerja dalam keluarga.

Kata Kunci : Usaha pemeliharaan Itik petelur, Manajemen

\section{ABSTRACT}

ANALYSIS OF LAYER DUCK FARMING MANAGEMENT IN THE DISTRICT OF WEST KAKAS

BARAT. This research was conducted in the District of West Kakas Minahasa regency in July-August 2016. This study aims to determine whether the layer duck farmers have implemented management functions (planning, organizing, implementing and monitoring) in the farming system of layer ducks. The villages of Kalawiran, Paso, Totolan, Wasian, Touliang, Panasen and Tontimomor have designated as study area, based on thecriteria: that these villages have population at least 200 head of layer ducks. The method of data collection was field survey. Data were primary data and secondary data. The sampling method of sample villages determined based on villages criteria that the village has layer duck population of over 200 head and the purposive sampling method of respondentbased on the following considerations: having a population of at least 200 head layer ducks and has been raising more than 1 year. Model analysis wasdescriptive analysis to describe qualitatively. Qualitative analysis was identify and described management principles were carried out in the system of raising layer ducks. The results showed that the characteristics of the level of respondent education were ungraduated of SD (18\%), SD (14\%), SMP (32\%), SMA $(36 \%)$. Duck farming experiences were $<5$ years 2 (9\%), 6-10 years and 11 $(50 \%),>11$ years $9(41 \%)$. Scales of duck farming were276-350 8 (36\%), 200-275 9
(40\%), 315-375 1 (5\%). Family labour was $22(100 \%)$. Analysis of management (planning, organizing, implementing, and monitoring) showed that almost all of the farmers have implemented the management functions within the traditionally farmingsystem of layer duck. Management of planning were $22(100 \%)$, monitoring 22(100\%), while the management of the organization and implementation was only $3(14 \%)$ and 19 $(86 \%)$ did not recorded the results, since most farmers rely on memory.It can be a weakness in the development of layer duck farming.Layer duck farming use only the family labour.

Keywords: Layer duck, farming, Management.

\section{PENDAHULUAN}

Peternakan berperan nyata dalam ketahanan pangan nasional melalui penyediaan protein hewani dan penyedia lapangan kerja baik di pedesaan maupun diperkotaan. Secara nasional industi perunggasan merupakan pemicu utama pertumbuhan pembangunan di Subsektor peternakan (Inounu dkk., 2006). Sub sektor peternakan dalam mewujudkan program pembangunan peternakan secara operasional diawali dengan pembentukan atau penataan kawasan melalui pendekatan sistem yang tidak dapat dipisahkan dari usaha peternakan yaitu meningkatkan pendapatan dan kesejahteraan masyarakat (Nurzaman, 2002).

Usaha peternakan merupakan salah satu bagian usaha yang sangat baik untuk dikembangkan dan hasil usaha peternakan 
juga sangat menguntungkan untuk dipasarkan. Salah satu usaha peternakan yang banyak digeluti oleh masyarakat adalah usaha peternakan itik petelur. Usaha peternakan itik petelur memiliki prospek usaha yang baik untuk dikembangkan, baik sebagai usaha pokok maupun usaha sampingan.

Khususnya di Kecamatan Kakas Barat Kabupaten Minahasa, usaha itik petelur banyak diminati oleh peternak karna sebagai alternatif sumber pendapatan dan juga disebabkan oleh kondisi lingkungan yang strategis untuk mengembangkan usaha pemeliharaan ternak itik petelur. Dari hasil prasurvei diketahui bahwa usaha beternak itik menjadi usaha turun termurun karena hasil yang di dapat mampu menunjang kebutuhan perekonomian masyarakat.

Potensi usaha itik petelur di Kecamatan Kakas Barat mempunyai peluang untuk dikembangkan karna dapat memberikan kontribusi bagi peternak. Pada umumnya itik petelur dipelihara oleh masyarakat masih tergolong tradisional, peternakan itik petelur dikatakan memiliki potensi karena permintaan di berbagai daerah tergolong besar. Namun untuk menunjang dan mengoptimalkan produksi telur itik maka dibutuhkan pengalaman dan pengertahuan akan sestem manajemen yang tepat. Faktor-faktor yang mempengaruhi keberhasilan usaha pemeliharaan ternak itik adalah kualitas bibit yang digunakan, kualitas pakan, pengalaman dalam sistem pemeliharaan ternak itik yang dikaitkan dengan adanya penerapan fungsi-fungsi manajemen dalam usaha pemeliharaan agar usaha yang dijalankan dapat lebih berkembang. Fungsi-fungsi manajemen meliputi proses Perencanaan (Planning), Pengorganisasian (Organizing), Pelaksanaanataupenerapan (Actuating) danPengawasan (Controlling).

Mengacu pada latar belakang penelitian, maka dapat dirumuskan permasalahanya yaitu apakahpeternakitik di Kecamatan Kakas Barat telahmenerapkanfungsifungsimanajemendalamkegiatanusaha pemeliharaan ternak itik petelur.

Tujuan utama penelitian ini adalah mengidentifikasidanmendeskripsikansiste m pemeliharaan itik petelur di Kecamatan Kakas Barat Kabupaten Minahasa berdasarkan fungsi-fungsi manajemen yang meliputi Perencanaan (Planning),Pengorganisasian (Organizing), PelaksanaanatauPenerapan (Actuating) danPengawasan (Controlling) dan juga mendeskripsikan karakteristik usaha ternak itik petelur di Kecamatan Kakas Barat Kabupaten Minahasa. 


\section{METODE PENELITIAN}

Penelitiandilaksanakanpada peternak itik petelur di Kecamatan Kakas Barat Kabupaten Minahasa.Waktu penelitian dilaksanakan pada bulan Juli sampai dengan bulan Agustus2016.

Penelitian survey merupakan suatu teknik pengumpulan informasi yang dilakukan dengan cara menyusun daftar pertanyaan yang diajukan pada responden. Data yang diambil dalam penelitian ini yaitu data primer dan data sekunder. Data primer ialah data yang diperoleh melalui wawancara langsung dengan responden yang berpedoman pada daftar pertanyaan (kuesioner) yang telah disediakan sertamelakukan teknik observasi dengan mengamati secara langsung dilokasi penelitian. Data sekunder ialah data yang diperoleh dari lembaga atau instansi yang terkaityaitu; Kantor Dinas Kehewanan Kabupaten Minahasa, kantor Dinas Kecamatan Kakas Barat, dan BP3K (Balai Penyuluhan Pertanian Peternakan Kecamatan Kakas). Data-data tersebu tmeliputi keadaan umum wilayah, keadaan penduduk, jumlah populasi ternak.

Penentuan sampel penelitian di Kecamatan Kakas Barat Kabupaten Minahasa dilaksanakan dalam dua tahap. Pertama penentuan desa sampel berdasarkan kriteria yaitu desa yang memiliki populasi ternak itik diatas 200 ekor. Purposive sampling ialah pengambilan sampel dipilih berdasarkan pertimbangan jumlah populasi dalam suatu wilayah (Singarimbun, 1986).

Kedua penentuan sampel responden juga dilakukan secara purposive sampling berdasarkan pertimbangan:

a) Memiliki populasiternak minimal 200 ekorternakitikdariberbagaijenis yang ada.

b) Sudah lebih dari1 tahun memelihara ternak itik

Tabel. 1. Jumlah Responden

\begin{tabular}{llc}
\hline No & Nama Desa & Responden \\
\hline 1 & Desa Kalawiran & 2 \\
2 & Desa Paso & 2 \\
3 & Desa Totolan & 2 \\
4 & Desa Wasian & 2 \\
5 & Desa Touliang & 4 \\
6 & Desa Panasen & 4 \\
7 & Desa Tountimomor & 6 \\
\hline & Total Responden & 22 \\
\hline
\end{tabular}

Pengertian dan batasan-batasan variabel yang digunakan dalam penelitian ini, ialah:

1. Jumlah ternak itik ialah semua populasi ternakitik yang di pelihara oleh peternak, diukur dalam satuan ekor.

2. Tenaga kerja ialah orang yang seharihari bekerja, menangani dan memelihara ternak itik, yang meliputi pemberian pakan dan minum ternak, 
pembersian kandang ternak, dihitung menggunakan jumlah curahan tenaga kerja jam/hari.

3. Pengalaman peternak ialah lamanya usaha beternak yang dihitung beternak itik, diukur dalam tahun.

4. Pendidikan ialah tingkat pendidikan formal yang dimiliki oleh petani peternak (SD, SLTP, SMA, Diploma, Sarjana).

5. Harga telur itiki alah nilai uang yang diterima dari hasil penjualan telur itik yang diukur dalam Rp/butir/periode ( 1 tahun ).

6. Harga ternak itik ialah nilai uang yang diterima dari hasil penjualan ternakitik afkir yang diukur dalam Rp/ekor/periode (1tahun).

7. Perencanaan (Planning) adalah persiapan awal sumberdaya yang dimiliki menyangkut ketersediaan modal awal, pengadaan bibit, pengadaan pakan, kandang, pengetahuan/pengalaman, dan pemasaran.

8. Pengorganisasian (Organizing) adalah berkaitan dengan pembagian tugas pekerjaan.

9. Pelaksanaan atau Penerapan (Actuating) adalah merupakan implementasi dari perencanaan dan pengorganisasian, dimana seluruh komponen yang berada dalam satu system tersebut bekerja secara bersama-sama sesuai dengan bidang masing-masing untuk dapat mewujud kan tujuan.

10. Pengawasan (Controlling) adalah pengendalian semua kegiatan dari proses perencanaan, pengorganisasian dan pelaksanaan, apakah semua kegiatan tersebut memberikan hasil dan sesuai dengan tujuan.

Metode analisis data yang digunakan dalam penelitian ini yaitu pendekatan analisis deskriptif dimaksudkan untuk menguraikan secara kualitatif. Analisis Kualitatif yaitu mengidentifikasi dan mendeskripsikan prinsip-prinsip manajemen yang dilakukan peternak dalam kegiatan pemeliharaan ternak itik dalam usahanya.

\section{HASIL DAN PEMBAHASAN}

Kecamatan Kakas Barat adalah salah satu Kecamatan di Kabupaten Minahasa sebagai hasil pemekaran dari Kecamatan Kakas. Kecamatan Kakas Barat dibentuk dengan Perda No. 1 Tahun 2010 tentang Pembentukan Kecamatan Kakas Barat dan Keputusan Bupati Minahasi Nomor 196 Tahun 2010 tentang Pengesahan Pembentukan Kecamatan Kakas Barat. Kecamatan Kakas Barat terletak pada 0'0913 LU - 1 dan 124'86 125'01 BT, juga terletak pada daratan dengan ketinggian antara 0-748m di atas 
permukaan laut. Bentuk wilayah daratan 44,44\%, lereng 55,56\%. Adapun Kecamatan Kakas Barat berbatasan wilayah dengan :Sebelah utara berbatas dengan Kecamatan Remboken dan Danau Tondano.Sebelah timur berbatasan dengan Kecamatan Kakas.Sebelah selatan berbatasan dengan Laut Maluku.Sebelah barat berbatasan dengan Kecamatan Langowan Timur, Kecamatan Langowan Selatan dan Kecamaran Tompaso.Kecamatan Kakas Barat terdiri dari 10 (sepuluh) desa dengan Ibukota Kecamatan di Desa Wasian.

Usaha ternak itik petelur pada umumnya merupakan usaha skala kecil (peternakan rakyat) sehingga hanya menggunakan tenaga kerja keluarga. Usaha ternak itik petelur diminati oleh masyarakat karena cara pemeliharaannya yang mudah dilakukan, usaha ini hampir dilakukan oleh setiap rumah tangga di wilayah ini karena didukung oleh kondisi wilayah yang masih memungkinkan digunakan untuk beternak itik. Jumlah ternak dalam usaha ini yang dipelihara oleh peternak (responden) berkisar 225 375 ekor itik dewasa.

Cara pemeliharaan dilakukan secara semi intensif dimana ternak dikandangankan dan sesekali digembalakan pada waktu musim panen padi guna mencukupi kebutuhan ternak itik petelur. Penjualan hasil ternak (telur, itik afkir) dilakukan di sekitar wilayah Kecamatan Kakas Barat dan pasar-pasar terdekat, tetapi ada juga konsumen yang datang sendiri untuk memberli hasil ternak (telur, itik afkir). Telur itik yang dihasilkan masih belum bisa memenuhi permintaan konsumen karena produk yang dihasilkan masih sedikit yang disebabkan cara pemeliharaan yang masih sangat sederhana. Harga pemasaran telur itik bervariasi mulai dari $\operatorname{Rp} .57 .500$ Rp.65.000/baki, khusus untuk itik afkir harganya Rp. 60.000/ekor.

Modal usaha merupakan elemen yang penting yang harus mendapatkan perhatian dalam menjalan kegiatan usaha, karena modal sangat menunjang dalam kelancaran kegiatan usaha. Menurut Bambang Riayanto (2001), menyatakan bahwa pengertian modal secara klasik adalah hasil produksi yang digunakan untuk memproduksi lebih lanjut. Responden dalam penelitian ini memiliki besar modal awal berkisar < Rp. 10.000.000, Rp.11.000.000- 15.000 .000 dan > Rp 16.000.000. Peternak (responden) dalam usaha pemeliharaan ternak itik petelur khususnya di Kecamatan Kakas Barat sebagian besar menggunakan tenaga kerja dalam keluarga ; ditemukan bahwa 22 responden 
menggunakan tenaga kerja dalam keluarga.

Manajemen pemeliharaan dalam penelitian ini mengenai analisis usaha pemeliharaan ternak itik petelur meliputi beberapa fungsi manajemen yaitu perencanaan, pengorganisasian, pelaksanaan atau penerapan dan pengawasan yang dikaitkan dengan aspekaspek pemeliharaan ternak itik petelur. Hasil Analisis manajemen dalam pemeliharaan ternak itik petelur di Kecamatan Kakas Barat menunjukkan bahwa pada umumnya usaha pemeliharaan yang dilakukan oleh responden hampir semua fungsi manajemen diterapkan dalam aspek pemeliharaan ternak itik yang dilakukan secara tradisonal, dimana ratarata presentase dalam perencanaan $22(100 \%)$ responden, pengawasan $22(100 \%)$ responden, namun dalam manajemen pengorganisasian dan pelaksanaan hanya $3(14 \%)$ yang menerapkan aspek pencatatan hasil, maka terdapat 19(86\%) tidak melakukan pencatatan peternak hanya mengandalkan ingatan saja.

Dari hasil penelitian dilihat bahwa yang sangat berperan dalam usaha pemeliharaan itik peterlur di Kecamatan Kakas barat yaitu kepala keluarga (bapak) dengan bantuan tenaga kerja keluarga (ibu dan anak). Pada umunya pemeliharaan ternak itik petelur di Kecamatan Kakas Barat sudah menerapkan fungsi-fungsi manajemen namun masih tradisional sesuai dengan pengetahuan dan pengalaman yang dimiliki peternak (responden).

\section{KESIMPULAN}

Peternak itik petelur di Kecamatan Kakas Barat dalam penerapan fungsifungsi manajemen perencanaan terdapat 22 (100\%), manajemen pengorganisasian khusus dalam pencatatan hasil hanya 3 (14\%) yang menerapkan, 19 (86\%) hanya mengandalakan ingatan saja, begitu juga dalam fungsi manajemen pelaksanaan atau penerapan hanya terdapat $3(14 \%), 19$ $(86 \%)$ hanya mengandalakan ingatan dalam pencatatan hasil dan fungsi pengawasan terdapat $22(100 \%)$ yang melakukan, dimana tenaga kerja yang digunakan adalah tenaga kerja dalam keluarga serta yang paling berperan dalam usaha pemeliharaan ternak itik petelur adalah bapak.

\section{SARAN}

Perlunya penyuluhan mengenai pentingnya penerapan fungsi-fungsi manajemen yang lebih baik lagi khususnya dalam pencatatan hasil, agar usaha yang dilakukan oleh peternak lebih berkembang 
serta dapat memenuhi permintaan konsumen di Kecamatan Kakas Barat.

\section{DAFTAR PUSTAKA}

Endoh, G.B., A. Makalew, M. A. V Manese, T. F. D Lumy Analisis Rentabilitas Usaha Ternak Itik Petelur di Desa Wolaang Kecamatan Langowan Timur Kabupaten Minahasa. Universitas Sam Ratulangi. 36(1): 198-206

Fayol, H. 1995. Industri dan Manajemen Umum, Terj.Winardi, London: Sir Issacand Son.

Inounu, I. , A. Priyanti, E. Martindah, I.S. Nurhayati dan R. A. Saptati. 2006. Restrukturisasi Sistem Produksi Perunggasan di Indonesia. Pusat Penelitian dan Pengembangan Peternakan. Badan Penelitian dan Pengembangan Pertanian. Bogor.

Ketaren, P. P. 2010. Kebutuhan Gizi Ternak Unggas di Indonesia. Wartazoa 20 (4) : 172-205.

Kustopo B dan M. Handayani. 2008. Analisis Profitabilitas Pengembangan Usaha Ternak Itik di Kecamatan Pagerbarang Kabupaten Tegal. Jurnal Mediargro. 5(2):1219.

Polakitan D, A.Dp.Mirah A., F.H. Elly, dan V.V.J. Panalewen . 2015. Keuntungan Usahatani Padi Sawah dan Ternak Itik di Pesisir Danau Tondano Kabupaten Minahasa. Zootek. 35(2): 361-367.

Prasetyo, L.H dan T. Susanti. 1997. Persilangan Timbal antara Itik Tegal dan Mojosari : I. Awal pertumbuhan dan awal bertelur. Jurnal Ilmu Ternak dan Veteriner 2(3) : 152-156.

Raharjo, B.K.D. 2009. Pengembangan Usaha Ternak Itik Di Kabupaten Tegal. Fakultas Peternakan Universitas Di Ponegoro. Semarang.

Setioko, A., S. Iskandar., Y.C. Raharjo., T.D.Soedjana., T. Murtisati., M. Purba., S.E.Estuningsih., N. Sunandar, dan D. Pramano. 2000. Model Usaha Ternak Itik dalam Sistem Pertanian IP Padi 300. Jurnal Ilmu Ternak dan Veteriner 5(1) : 3845.

Singarimbun,M. 1989. Metodedan Proses Penelitian.MetodePenelitianSurvai. LP3ES, Jakarta. 